Tourism Research Journal

E-ISSN: 2598-9839

2018, Vol. 2 No. 1

\title{
Customer Retention Strategy Through Customer Satisfaction and Customer Loyalty: The Study on Traveloka Loyalty Program
}

\author{
Fiona Poetri Komalasari ${ }^{1}$, Surya Fajar Budiman ${ }^{2}$ \\ ${ }^{1,2}$ Sekolah Tinggi Pariwisata Trisakti \\ 1 fionapoetrikomalasari@gmail.com
}

\begin{abstract}
Customer loyalty and customer retention is very closely related, customer loyalty stopped customer churn and strengthen the customer retention. The primary aim of retention strategy is to build a strong customer base and to prevent them from drifting towards other competitor. Traveloka as a travel supplier company, is the leading online travel agent in Indonesia. The customers satisfaction has an average score of 3,91. The result signify that Traveloka is successful in obtaining its customers' satisfaction The customer loyalty has an average score of 4,04. Traveloka has managed to reach customer loyalty Traveloka customer satisfaction and loyalty are obtained as presented through chapter IV that the average is 3,97. In this research, Traveloka customer retention strategy using loyalty program is proven to be effective.
\end{abstract}

Keywords: customer retention, customer satisfaction, customer loyalty, loyalty program, Traveloka.

\section{A. Introduction}

Tourism industry has started to rise with the help of government support, including other aspects. Online travel agent has also contributed a huge portion of tourism by making traveling easier, faster and cheaper. Numbers of notable online travel agents have risen in Indonesia and each one of them competing to be the best by providing a wide range of products, easy to use applications and many other marketing strategies including loyalty point program to obtain customer retention. Loyalty programs are structured marketing strategies designed by merchants to encourage customers to continue to shop at or use the services of businesses associated with each program. The loyalty programs encourage provide reward points for customers that encourage them to purchase more frequently and in larger volumes. The reward points are redeemable into a free service, upgrade in class or exchange in another product. 
PT. Trinusa Travelindo or widely known as Traveloka is Indonesia's $3^{\text {rd }}$ unicorn start-up company. Traveloka uses a structured marketing strategy by providing numerous promo codes and loyalty program named Traveloka Points. The loyalty program was launched to public on April 25 th, 2017 . Companies often measure customer retention using their own internal data. Meanwhile, customer retention is best to measure using public's opinions to pinpoint the actual strength and weakness.

Customer retention is measured by customer satisfaction which is a goal every company has. Not all customers feel satisfaction towards a company because each individual's level expectation is different. As for customer loyalty, this stage is what company aims for because obtaining customer loyalty brings profit and lower competition rate with substitute companies.

\section{B. Literature Review}

Customer retention is the activities and actions companies take to reduce the number of customer defections. The primary aim of retention strategy is to build a strong customer base and to prevent them from drifting towards other organisation for the same product or service. Singh and Imran (2012) stated that retention programs aim to turn the occasional customer into a frequent customer; they would be more likely to recommend the business to their friends and relatives. This stage comes when the customer decides to buy a product or service for the second time from the same provider. According to Muhammad (2013), a customer retention strategy is based on customer satisfaction and customer loyalty.

Loyalty program is a structured marketing effort that reward and encourage loyal buying behaviour, which is potentially beneficial to the firm (Sharp et al, 1997:86). The loyalty programs encourage them to purchase more frequently and in larger volumes. The reward points are redeemable into a free service or exchange in another product.

Customer satisfaction is defined as predetermined by how the expectations of the customer are met (Kotler et al., 2013). Customer satisfaction has been a major goal for business organizations for many years and that loyal customers contribute to the company's profitability by spending more on the company's products and services. According to Zeithaml \& Bitner (2006) there are five factors that determinate customer satisfaction; product and service feature, customer emotion, attributions for service success and failure, perception of equity and fairness, other consumer's experience.

Customer loyalty and customer retention is very closely related, customer loyalty stopped customer churn and strengthen the customer retention. When the company knows the mind of customer then it's easy to build the long term profitable relationship with their consumer and easily they could be loyal. According to Robinette (2001) these are factors impacting customer loyalty; caring, trust, length of patronage and overall satisfaction.

\section{Research Methodology}

This research uses quantitative method and only uses independent variables which are customer satisfaction and customer loyalty. The independent variables are then used as parameters to determine customer retention. The independent variable is a mixture of customer satisfaction and customer loyalty towards the Traveloka Points loyalty program.

Tourism Research Journal, Volume xx (x), 2018 
This research uses purposive sampling technique which is a type of nonprobability sampling that is most effective when one needs to study a certain cultural domain with knowledgeable experts within. A total of 100 questionnaires are distributed to respondents that are eligible to this research purpose as stated in the research population segmentation. Eligible respondents are ones who have Traveloka account, reside within Indonesia with age above 18 years old and have purchased two or more flight and/or hotel products from Traveloka.

Primary data collection method for this research is survey through questionnaires. Questionnaire is a research instrument to gather information from respondent and consists of carefully constructed questions related to the research study. The questionnaire was carefully designed with 23 questions suitable for the research purpose. Secondary data collection for this research will be collected through existing literature review related to this research study that are done by professionals.

The data analysis in this research starts from data preparation, data collection, data calculation and interpretation. The result of data analysis is summarized in the conclusion. The data will be collected through 100 questionnaire that has been distributed online using google forms. The respondents must fall under category of Indonesian residents, Traveloka members and have purchased at least one flight and/or hotel product though Traveloka. The acquired data from the questionnaire is calculated using excel to find out the topic average and overall average to be compared with Likert scale. The result is indicated as positive if the average is above 2,60. Susan (2004: 1217-1218) defines the Likert Scale as a psychometric response scale primarily used in questionnaires to obtain participant's preferences or degree of agreement with a statement or sets of statements. Likert scale used in this research is Strongly Disagree, Disagree, Mostly Agree, Agree, Strongly Agree. Written in sequence from 1 to 5, the lowest number as negative and higher number as positive. The result is expressed in Descriptive analysis are used to present quantitative descriptions in a manageable form and describe the basic features of the data in a study.

\section{Result}

This research questionnaire was distributed mainly to Traveloka active users to collect data more precisely towards the research purpose. A total of 100 eligible respondents have participated in the research questionnaire and resulted in the data presented below.

Table 1: Respondents Gender

\begin{tabular}{cccc}
\hline Variable & Description & Frequency & Percentage \\
Gender & Male & 39 & $39 \%$ \\
& Female & 61 & $61 \%$ \\
& Total & $\mathbf{1 0 0}$ & $\mathbf{1 0 0}$ \\
\hline
\end{tabular}

As presented in Table 1, most of the respondents are female with a total of 61 people (61\%), followed by male respondents with a total of 39 people $(39 \%)$. 
Customer Retention Strategy Through Customer Satisfaction and Customer Loyalty: The Study

On Traveloka Loyalty Program

Table 2: Respondents Age

\begin{tabular}{cccc}
\hline Variable & Description & Frequency & Percentage \\
\hline \multirow{3}{*}{ Age } & $18-20$ & 3 & $3 \%$ \\
& $21-23$ & 67 & $67 \%$ \\
& $24-26$ & 21 & $21 \%$ \\
& $\geq 27$ & 9 & $9 \%$ \\
\hline & Total & $\mathbf{1 0 0}$ & $\mathbf{1 0 0}$ \\
\hline
\end{tabular}

The respondents are dominated with 67 people age 21 to 23 years old (67\%), followed by 21 people age 24-26 (21\%), 9 people age 27 and above (9\%) and lastly 3 people age $18-20(3 \%)$.

Table 3. Respondents Purchase Frequency

\begin{tabular}{cccc}
\hline Variable & Description & Frequency & Percentage \\
\hline \multirow{3}{*}{ Purchase } & 1 time & 3 & $3 \%$ \\
Frequency & 2 times & 9 & $9 \%$ \\
& 3 times & 5 & $5 \%$ \\
& More than 3 times & 83 & $83 \%$ \\
\hline & Total & $\mathbf{1 0 0}$ & $\mathbf{1 0 0}$
\end{tabular}

Respondents' purchase frequency, 83 people have purchased more than 3 flight and/or hotel products (83\%), 9 people have only purchased 2 flight and/or hotel products (9\%), 5 people have only purchased 3 flight and/or hotel products $(5 \%)$, and 3 people have only make their first purchases of flight and/or hotel through Traveloka.

Table 4: Questionnaire Data Calculation

\begin{tabular}{|c|c|c|c|c|}
\hline \multicolumn{2}{|c|}{ Description } & $\begin{array}{c}\text { Topic } \\
\text { Average }\end{array}$ & $\begin{array}{c}\text { Overall } \\
\text { Average }\end{array}$ & Average \\
\hline $\begin{array}{l}\text { Customer } \\
\text { Satisfaction }\end{array}$ & $\begin{array}{c}\text { Product and } \\
\text { Service Feature } \\
\text { Customer } \\
\text { Emotion } \\
\text { Attribution for } \\
\text { Service Success } \\
\text { and Failure } \\
\text { Perception of } \\
\text { Equity and } \\
\text { Fairness } \\
\text { Other Consumer's } \\
\text { Experience }\end{array}$ & 3,94 & 3,91 & 3,97 \\
\hline
\end{tabular}

Tourism Research Journal, Volume xx (x), 2018 


$\begin{array}{cccc} & \text { Caring } & 3,96 & \\ & \text { Trust } & 4,22 & \\ \text { Customer } & \text { Length of } & 4,00 & 4,04 \\ \text { Loyalty } & \text { Patronage } & & \\ & \text { Overall } & 3,99 & \end{array}$

Overall, the customers satisfaction has an average score of 3,91. The result signify that Traveloka is successful in obtaining its customers' satisfaction by providing the easiest application for user, fast transaction process, equal treatment towards its customers and other innovation. Proofing that customers do expressed their satisfaction towards Traveloka.

Overall, the customer loyalty has an average score of 4,04. Traveloka has managed to reach customer loyalty by providing care for all customers, maintaining and growing brand image to become a trustworthy company, proffesionals to take care of its customers and defend its overall satisfaction. Indicating that customers do expressed loyalty towards Traveloka.

Following Muhammad (2013) theory, customer retention strategy is based on customer satisfaction and customer loyalty. Satisfied customer and loyal customer result in effective customer retention. Traveloka customer satisfaction and loyalty are obtained as presented through chapter IV that the average is 3,97. Therefore, in this research, Traveloka customer retention strategy using loyalty program is proven to be effective, the loyalty program impacts positively towards customer retention and the hypothesis of this research are true.

Product awareness is the key to measure one's success. From the product are service feature, it shows that Traveloka members are aware and knowledgeable of loyalty program called Traveloka Points with average result of 3,77. Most customers have earned as well as redeemed their loyalty points in exchange of other product or service available for point redemption. Consumer emotions played a significant role with the product or services satisfaction. The customer emotion average score is 3,62 and the results show that customers are happy when loyalty points are earned and redeemed into a more valuable product or service. The attributions for service success and failure play a significant role in customer satisfaction and in this research, it has the highest average score of 4,26. The user-friendly application and successful transactions help customer satisfaction level increases. Customers' perception of equity and fairness average result is 3,95. The result shows that Traveloka has a good business model that treats their customers equally. When customers are treated fairly, they're more likely to be satisfied. Human is a social creature, heavily influenced by other people's experience. This research shows that other people's experience upon using Traveloka is positive, with an average result of 3,94. Therefore, they're more likely to recommend it to their family, relatives and/or friends.

Customer loyalty can be obtained if the company cares for its customers. Caring between company and customers is established by company's innitiative to provide customer platform to interact with the company. The average result is 3,96 meaning that customers agree that Traveloka has tried their best to provide a multi-product platform for its customer. Trust is the core element for a company to grow customer loyalty. Trust 
has the highest average score of 4,22. This element plays a big part in customer loyalty for Traveloka. From this research, customers agree that Traveloka is trustworthy and has a positive brand image. Traveloka is expected to provide platforms for their customers to ask, complain and interact with the company representatives. The length of patronage average result is 4,00. The result of this research shows that Traveloka maintain its customer loyalty by hiring professionals to cope with customers' request and problems. The overall satisfaction is measured by customers starting from overlooking the application, purchasing, earning and redeeming points, including other aspects of Traveloka. The average result is 3,99 meaning that customers are overall satisfied of Traveloka. As presented in this research, overall customers are satisfied of Traveloka product, service and its loyalty program.

\section{E.Discussion}

The result of this result is positive with all topic average exceeding 3,04 meaning that Traveloka is successful in obtaining customer satisfaction and customer loyalty using loyalty program marketing strategy that resulted in effective customer retention. As set from the beginning, one of the research objectives is to find better solutions to increase Traveloka loyalty program competitive advantage.

This research help to identify which aspects are potential to be improved. From the sub-category product and service feature, Traveloka should consider to provide more selections of product and service for point redemption. Therefore the loyalty program can be more appealing. A negative response appear on the sub-category perception of equity and fairness. Number of customers consider the loyalty program to be unfair because the program is only applicable for flight and/or hotel products.

Traveloka should consider to expand their loyalty program eligibility in other products such as train, bus, airport transfer and other products available on the application. Therefore, more members are able to join the loyalty program and earning Traveloka Points could be easier. This should be a parameter for companies to shift their focus on maintaining customer retention in order to lower marketing expenses and increase profit from loyal repeating customers.

\section{F. Conclusion}

This research concludes that customer satisfaction and customer loyalty play an important role in the aim for customer retention. When customers feel satisfied towards a company, customers tend to repurchase and expand their experience to the surroundings.

Added with customer loyalty towards a company, the customers expressed trust and intention to repeat their purchase in form of bigger volume or higher frequency of buying. Customer satisfaction and customer loyalty combined make a great customer retention rate. Making brands more valuable and for companies to lower their expenses in obtaining new customers because managing existing customers is easier and cost effective. Since existing customers are already aware of what the company offers and expressed interest towards the product and service available. Traveloka as a leading online based travel agent is successful because of its carefully structured loyalty program to reward its loyal customers in exchange of their purchases. 
Customer Retention Strategy Through Customer Satisfaction and Customer Loyalty: The Study On Traveloka Loyalty Program

\section{REFERENCES}

Kotler, P., Bowen, J., Makens, J. (2013). Marketing for Hospitality and Tourism. Pearson education, Inc. Upper Saddle River.

Muhammad, N.R. (2013). Customer Retention Strategies of Compressed Natural Gas (CNG) in a Developing Country (Pakistan). Linnaeus University.

Sharp, B. \& Sharp, A. (1997). Loyalty Programs and Their on Repeat- Purchase Loyalty Patterns. International Journal of Research in Marketing, 14 (5), 473-86.

Singh, R. \& Imran, K. (2012). An Approach to Increase Customer Retention and Loyalty in B2C World. International Journal of Scientific and Research Publications, Volume2, Issue 6.

Susan, J. (2004). Likert Scales: How to (Ab)Use Them. Medical Education 38: 1217-1218.

Zeithaml, V., Bitner, M. (2016). Services Marketing. New York: McGraw-Hill. 